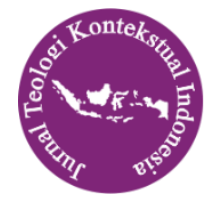

Jurnal Teologi Kontekstual Indonesia

ISSN: 2722-8630 (online)

https://journal.sttsimpson.ac.id/index.php/JTKI/

Vol. 1, No. 1 (2020): 26-37

DOI : 10.46445/jtki.v1i1.293

\title{
Spiritualitas Orang Kristen Dalam Menghadirkan Kerajaan Allah di Tengah Tantangan Radikalisme
}

\author{
Martina Novalina \\ Sekolah Tinggi Teologi Ekumene Jakarta \\ Email: martina@sttekumene.ac.id
}

\begin{abstract}
Radicalism is not a new term in the life of this nation. In the midst of these challenges, the role of one's spirituality will greatly help this nation, as well as those of Christian spirituality; how Christians can present God's Kingdom in the midst of these challenges. The discussion in this article uses a qualitative approach. While the research writing technique used is literature review or literature study. The results showed that the Christian spirituality presented in the community must be able to provide shade for the plural society in Indonesia, not just cause noise. The radical attitude of Christians in carrying out their faith does not have to be manifested through extreme demonstrations but the radical actions of Christians must be able to bring Christians to be witnesses and bring peace, justice and love to others; show concern for others and society. The spirituality of Christians must also touch the field of education, and emotional development. All of the above are possible to do in this nation and present the Kingdom of God in the midst of the challenges of radicalism.
\end{abstract}

Keywords: Radicalism, Spirituality, God's Kingdom, Christianity

\begin{abstract}
Abstrak
Radikalisme bukanlah sebuah istilah baru yang ada dalam kehidupan bangsa ini. Di tengah tantangan tersebut, peran spiritualitas seseorang akan sangat membantu bangsa ini, begitu juga dari kalangan spiritualitas orang Kristen; bagaimana orang Kristen bisa menghadirkan Kerajaan Allah di tengah tantangan tersebut. Pembahasan dalam artikel ini menggunakan pendekatan kualitatif. Sedangkan teknik penulisan penelitian yang digunakan adalah literature review atau studi pustaka. Hasil penelitian menunjukkan bahwa spiritualitas orang kristen yang dihadirkan dalam masyarakat harus bisa memberikan keteduhan bagi masyarakat plural di Indonesia, bukan justru menimbulkan kegaduhan. Sikap radikal orang Kristen dalam menjalankan imannya tidak harus diwujudkan melalui demonstrasi ekstrim tetapi tindakan radikal orang kristen haruslah mampu membawa orang Kristen menjadi saksi dan membawa damai, keadilan dan kasih bagi sesamanya; menunjukkan kepedulian terhadap sesama dan masyarakat. Spiritualitas orang kristen pun harus menjamah bidang pendidikan, dan pembinaan emosi. Semua hal tersebut di atas memungkinkan untuk dilakukan dalam bangsa ini dan menghadirkan Kerajaan Allah di tengah tantangan radikalisme.
\end{abstract}

Kata kunci: Radikalisme, Spiritualitas, Kerajaan Allah, Kristen.

\section{Pendahuluan}

Dalam sebuah survei yang dilakukan oleh The Pew Research Center pada tahun 2015 lalu, terungkap bahwa di Indonesia, sekitar 4\% atau sekitar 10 juta orang warga Indonesia mendukung ISIS - sebagian besar dari mereka merupakan anak-anak muda. Data tersebut dapat dilihat dari gambar di bawah ini: ${ }^{1}$

\footnotetext{
${ }^{1}$ Bbc.com, "The Pew Research Center."
} 
Gambar 1. Survey The Pew Research Center tahun 2015

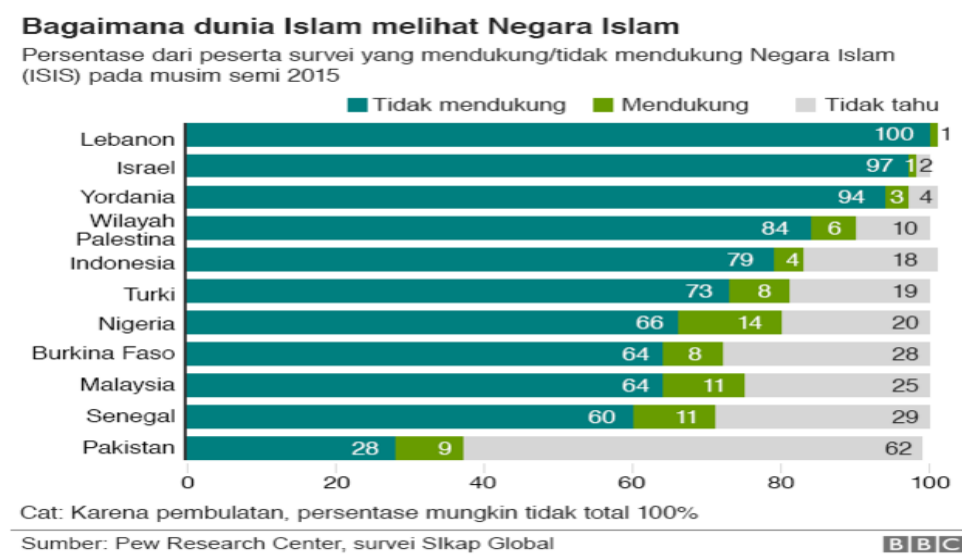

Pada tanggal 1 Agustus 2017, The Pew Research Center mengeluarkan hasil survei tentang pandangan global terhadap ancaman-ancaman bagi keamanan negara-negara di dunia. Hasil survei tersebut menyatakan bahwa secara global, ancaman terbesar bagi negara-negara adalah ISIS, dimana Indonesia merupakan salah satu negara yang menganggap ISIS (74\%) adalah ancaman terbesar bagi bangsa ini, disamping kondisi ekonomi global (58\%) dan perubahan iklim secara global $(56 \%)^{2}$.

Angka 4\% yang menunjukkan dukungan terhadap ISIS bukanlah jumlah yang sedikit untuk bisa merusak persatuan bangsa ini. Dan angka $74 \%$ tersebut menunjukkan bahwa radikalisme merupakan isu yang perlu diperhatikan dengan serius di bangsa ini. Pemahaman radikalisme ini jika dibiarkan terus menerus akan menyuburkan sikap intoleran dan menyebabkan disintegrasi bangsa. Itulah mengapa, pemerintah menganggap dikeluarkannya Undang-Undang no 2 tahun 2017 merupakan salah satu langkah tepat dalam menangani masalah radikalisme ini. Namun, apakah cukup hanya dengan mengeluarkan Undang-Undang Ormas tersebut? Karena bagi pihak tertentu UU Ormas yang baru menurunkan indeks demokrasi. ${ }^{3}$

Radikalisme agama bukanlah perbuatan satu golongan maupun agama tertentu saja, sekalipun yang nampak nyata di permukaan bumi Indonesia saat ini berasal dari mereka yang menamai dirinya aliran/golongan bernuansa Islam. Dari pihak agama lain pun ternyata ada yang melakukan tindakan radikal, sekalipun tidak secara langsung melakukan kekerasan fisik namun mendatangkan kekerasan fisik dari pihak yang merasa dirugikan. Hal ini dapat dilihat dari hasil penelitian Novalina yang menyatakan bahwa kekerasan atas nama agama dimiliki oleh setiap agama yang ada di Indonesia, namun bukan berdasarkan karena pengajarannya semata tetapi lebih kepada faktor politik kotor yang membelakanginya. Selain itu, faktor keteladanan pemimpin agama yang tidak baik ikut ambil bagian dalam sikap radikalisme destruktif di kalangan umat. ${ }^{4}$

2 pewglobal, "Http://Www.Pewglobal.Org/2017/08/01/Globally-People-Point-to-Isis-and-ClimateChange-as-Leading-Security-Threats/."

${ }^{3}$ cnnindonesia, "Gerindra-Tunggu-Putusan-Mk-Untuk-Koreksi-Uu-Ormas."

4 Martina Novalina, Di Bawah Kepak Sayap Sang Garuda (Pemahaman, Sikap Dan Tindakan Fundamental Keber-Agama-an Dalam Bingkai Pancasila), ed. Tim STT Ekumene, 1st ed. (Jakarta: Rehobot Literature, 2018). 
Maka dengan latar belakang yang telah dipaparkan, terdapat beberapa rumusan masalah sebagai berikut: Apakah radikalisme itu? Mengapa ada radikalisme? Apakah sebenarnya yang dimaksud dengan tindakan radikal di kalangan orang Kristen sendiri? Apakah peran gereja dalam menghadapi radikalisme yang ada? Dapatkah orang Kristen menghadirkan kerajaan Allah di tengah-tengah tantangan radikalisme ini? Dalam penelitian ini, peneliti menfokuskan pembahasan kepada bagaimana orang Kristen menghadirkan Kerajaan Allah di tengah tantangan radikalisme.

\section{Metode}

Pembahasan dalam artikel ini menggunakan pendekatan kualitatif. Sedangkan teknik penulisan penelitian yang digunakan adalah literature review atau studi pustaka. Teknik ini digunakan karena artikel ini merupakan sebuah kajian teoritis, referensi serta literatur ilmiah yang berhubungan dengan budaya, nilai, dan norma yang berkembang dalam situasi sosial saat permasalahan yang ada diteliti sebagaimana yang diungkapkan Putri. ${ }^{5}$ Data primer diperoleh melalui literature research, sedangkan data sekunder diperoleh dari jurnal, majalah, surat kabar dan sumber-sumber relevan lainnya. Tahapan penulisan ini dimulai dengan menentukan masalah dari perumusan masalah yang ada, kemudian melakukan evaluasi terhadap sumbersumber, membuat rangkuman dari sumber-sumber tersebut, dan akhirnya membuat literature review atau tinjauan pustaka.

\section{Pembahasan}

Radikalisme, fundamentalisme, konservatisme, ekstrimisme, dan terorisme dalam banyak tulisan jurnalistik sering dipakai secara bergantian. Kendati secara konseptual maknanya berbeda-beda, dalam praktik batas-batasnya memang seringkali kabur. Radikalisme adalah suatu paham atau aliran dalam politik yang menginginkan perubahan atau pembaharuan sosial dan politik dengan cara kekerasan atau drastis; sikap ekstrem dalam aliran politik. ${ }^{6}$ Dalam dunia politik, radikalisme dapat dipahami sebagai suatu pemikiran atau suatu tindakan revolusioner yang langsung bersentuhan dengan "akar-akar" (Latin: radix, radices) suatu persoalan dalam kehidupan suatu negara, yang ingin dicabut seluruhnya dan "pohon"-nya ditumbangkan; yang dalam istilah bahasa Indonesia disebut juga sebagai makar. Makar dalam KBBI didefinisikan sebagai "perbuatan atau usaha menjatuhkan pemerintah yang sah." ${ }^{, 7}$ Radikal memang tidak sama dengan radikalisme, tetapi tindakan radikal bisa menimbulkan radikalisme. Radikal sendiri dalam KBBI diartikan sebagai secara mendasar (sampai kepada hal yang prinsip), amat keras menuntut perubahan (undang-undang, pemerintahan) (dalam politik); atau maju dalam berpikir atau bertindak. ${ }^{8}$

\footnotetext{
${ }^{5}$ Putri Agustin Soewitomo, "Tips Dan Trik Pemilihan Dan Penyusunan Literatur Review," in Strategi Menulis Jurnal Untuk Ilmu Teologi (Golden Gate Publishing, 2020), 44.

${ }^{6}$ KBBI, “Radikalisme,” last modified 2020, https://kbbi.web.id/radikalisme.

${ }^{7}$ KBBI, "Makar."

${ }^{8}$ KBBI, "Radikal."
} 
Dalam pandangan dunia keagamaan yang totalitarian (menyatukan agama dengan politik), radikalisme religius menggiring orang beragama ke dalam suatu tindak kekerasan fisik, yang bertujuan makar, yakni menggulingkan suatu pemerintahan yang sah (yang dinilai sekular atau condong sekular) dan menggantikannya dengan suatu bentuk pemerintahan teokratis (Allah sebagai pemerintah, lewat wakilnya di dunia yang dilantik-Nya) atau pemerintahan nomokratis (hukum-hukum Allah dalam suatu agama menjadi UUD suatu negara).

Kaum radikal melawan siapa saja yang dianggap berada di luar, atau berbeda dengan pandangan hidupnya. Pandangan dan gaya hidup yang tidak sama dengan kelompoknya akan dengan mudah dianggap sebagai "musuh" paling nyata, sehingga tidak segan-segan untuk dimusnahkan. Dari sini kemudian berkembanglah cara pandang yang sangat intoleran, tertutup dan memutlakkan apa yang menjadi pandangannya. Klaim akan kebenaran akhirnya tidak bisa dipisahkan dari kaum radikal. Munculnya klaim ini di samping karena cara pandang kaum radikal yang berbeda dengan kaum nonradikal, juga disebabkan karena cara beragama yang sangat tekstual-skriptural. Cara pandang sangat menentukan bagaimana kaum radikal bersikap dan bertindak dalam beragama.

Radikalisme religius juga berarti fanatisme atau ekstrimisme atau fundamentalisme, yang tidak bersifat totalitarian mutlak, namun juga bisa bermuara pada kekerasan, baik kekerasan fisik (physical violence), maupun kekerasan wacana verbal (discourse/verbal violence). Kekerasan wacana ini muncul ketika seorang yang fanatik dengan agamanya sendiri menyerang agama-agama lain dengan membabibuta dengan maksud menjatuhkan agama-agama lain itu, melalui ucapan-ucapannya, khotbah-khotbahnya, ajaran-ajarannya, atau tulisan-tulisannya yang tidak memiliki landasan akademik sama sekali, tetapi merupakan propaganda-propaganda atau kampanye-kampanye 'hitam' (black campaign) yang diarahkan kepada agama-agama lain yang tidak disukainya. Kekerasan wacana dari radikalisme religius kerap memicu kekerasan fisik yang dilakukan pihak umat beragama yang merasa diserang.

Pembentukan Negara Kesatuan Republik Indonesia (NKRI) bukan hanya merupakan peristiwa politik yang mengubah penataan wilayah yang semula di bawah administrasi Hindia-Belanda. Pembentukan NKRI juga merupakan peristiwa kebudayaan menyangkut perubahan identitas. Dari masyarakat yang hidup berdasarkan prinsip kesukuan, keagamaan, budaya dan tata kelola kerajaan lokal, cita-cita NKRI mengarahkan penduduknya kemakna kebangsaan yang bersatu berdasarkan prinsip kewarganegaraan. ${ }^{9}$ Sekurang-kurangnya perubahan itu mencakup dua hal. Pertama, ke-Indonesia-an mengandung makna kesetaraan manusia dan kesamaan hak dalam komunitas politik nasional. Kedua, pengertian sosiokultural seperti kemajemukan budaya dan suku, keragaman agama, keadilan sosial dan lain-lain masuk ke dalam bingkai civic (Civic disini diartikan sebagai keyakinan, komitmen, kemampuan, sikap dan tindakan setiap orang sebagai warga komunitas/masyarakat/bangsa/negara).

${ }^{9}$ M. Sastrapratedja, Pancasila: Lima Gagasan Yang Dapat Mengubah Indonesia (Jakarta: Pusat Kajian Filsafat dan Pancasila, 2013). 
Dalam kedua bingkai tersebut, perdebatan untuk menetapkan apakah Indonesia merupakan negara agama atau bukan pada akhirnya ditampung dalam sila pertama dasar negara. Padahal, bagi banyak kebanyakan penganutnya, identitas keagamaan tidak berdiri di asas yang sama dengan identitas warga negara, jender, suku, ras dan lainnya. ${ }^{10}$ Jajak pendapat Kompas juga mengemukakan fakta bahwa orang Indonesia merasa penting, dan bahkan sangat penting, dikenal dalam masyarakat berdasarkan identitas kedaerahan, suku/etnis dan agama, baru kemudian sebagai warga dunia dan bangsa Indonesia. ${ }^{11}$

Agama pada dasarnya juga mengatur prinsip hidup bersama di dunia. Namun, dengan fungsi eskatologisnya, motivasi agama tidak sama dengan motivasi dalam prinsip-prinsip $c i$ vic. Prinsip civic mengacu ke hidup bersama di dunia secara inklusif-pengakuan akan kesetaraan setiap warga negara tanpa keberpihakan pada agama, ras dan etnisitas. Sumber prinsipprinsip civic banyak yang dapat ditelusuri ke ajaran agama. Kendati demikian, pertimbangan civic menghasilkan prinsip-prinsip normatif dan keutamaan (virtue) yang pembenarannya tidak bergantung pada kepercayaan ada atau tidak adanya daya-daya transenden. Contohnya adalah hak-hak asasi manusia. HAM diakui sebagai hak yang dimiliki setiap orang sematamata karena ia manusia, terlepas dari pertaliannya dengan agama atau institusi lainnya.

Priyono berpendapat bahwa radikalisme agama biasanya tidak berawal dari perkara agama atau teologi sendiri, meskipun itu tidak berarti agama hanyalah superstruktur kondisi sosial, ekonomi atau politik. Dalam penelitian lapangan (Juni-November 2013) terhadap lebih dari 600 orang muda yang direkrut dan bergabung dengan kelompok Boko Haram, misalnya, ditemukan pemicunya bukan persoalan agama melainkan frustasi pada kemiskinan dan pengangguran yang tercampur dengan tingginya buta-huruf dan lemahnya struktur keluarga. Kemudian, ideologi radikal menyediakan anak-anak muda ini cara berpikir baru dengan penjelasan mengapa dunia begini; mobilisasi seiring keberadaan mereka, mengubah retorika menjadi aksi. Begitu pula munculnya gelombang fundamentalisme Hindu di India pertama-tama bukan perkara agama, tetapi konflik elektoral terutama antara Bharatiya Janata Party (BJP) dan Indian National Congress (INC). Dalam arti, rujukan transenden sebagai bagian praktik agama dengan mudah didayagunakan menjadi wahana absolutisasi. ${ }^{12}$

Juergensmeyer menganalisa bahwa tidak semua orang mau menjadi teroris dan tidak semua orang terbujuk oleh daya pikat 'mati demi Tuhan'. Mereka yang sepaham tetapi tidak mau bergabung langsung umumnya bersedia menjadi pendukung. Mungkin mereka membayangkan bahwa mimpi utopis-eskatologisnya akan terwujud melalui aksi kelompok radikal tertentu, tanpa mereka sendiri perlu terlibat sebagai pelaku. Kelompok-kelompok ini terjaring melalui ragam komunikasi yang tersebar di internet (twitter, youtube, google Earth, chatrooms, e-group, virtual message boards) dan sarana interaktif lain yang mudah dijangkau.

\footnotetext{
${ }^{10}$ Franz Magnis Suseno F. Budi Hardiman (ed.), Tribalisme Menabrak Demokrasi Dalam Sosok Dan Pemikirannya Frans Magnis Suseno (Jakarta: Penerbit Kompas, 2016).

${ }^{11}$ Kompas, “Jajak Pendapat Kompas: 'Konflik Identitas Dan Kegaduhan Politik,” 2016. Magnis Suseno.

${ }^{12}$ F. Budi Hardiman (ed.), Tribalisme Menabrak Demokrasi Dalam Sosok Dan Pemikirannya Frans
} 
Perangkat bagi penyebaran ide-ide radikal dan ujaran kebencian (rasisme, homofobia, dsb) kini ada dalam kantung masing-masing.

Orang-orang yang terekrut oleh kelompok radikal kerap memajang foto dan video yang tampak gagah dan heroik. Mereka memanggul senjata dan siap bertarung demi tujuan besar yang jauh melampaui gugus egoistik manusia. Internet menyediakan fasilitas yang efektif dan efisien bukan hanya untuk memproduksi dan mereproduksi gagasan-gagasan radikal, melainkan juga untuk membangun efek dramatik yang ingin dimunculkan. Bagi kelompok radikal, efek dramatik itu perlu. Analisis Juergensmeyer melihat bahwa tindakan teror tidak melulu bertujuan strategis-politis. Kelompok teroris membangun theater of terror yang berfungsi sebagai sarana simbolik bagi perang kosmis: setan tidak dapat ditransformasikan, hanya bisa dimusnahkan. ${ }^{13}$

Teknologi informasi dan komunikasi juga semakin ramah terhadap wanita-pemudaanak-anak sehingga pihak yang terpapar oleh gagasan-gagasan radikal semakin luas dantak terduga. Itulah mengapa didapati banyak aksi radikalisme yang dilakukan dari kalangan usia muda. Teknologi yang diciptakan bagi kemudahan komunikasi kini menjadi teknik yang manjur untuk memancing kebencian dan membangkitkan kemarahan. Gejala ini bersifat global dan tidak hanya melibatkan kelompok teroris, tetapi juga orang-orang biasa yang tidak memiliki hubungan dengan ideologi radikal.

Setiap negara mengambil langkah yang berbeda-beda dalam menghadapi problematika tersebut. Apapun kebijakan yang diambil, corak media terhubung tidak sama dengan media tradisional. Media tradisional lebih mudah dikenai peraturan pemerintah dan bahkan diberedel. Di satu sisi, teknologi yang bermanfaat ini sangat disayangkan bila harus diberangus. Terorisme tidak akan lenyap hanya dengan hilangnya salah satu sarana teknologis pendukungnya. Di sisi lain, tidak mudah mengatasi tantangan penggunaan internet untuk menghimpun kebencian global. Hampir semua grup militan sekarang hadir secara terhubung di tengahtengah masyarakat.

Di tengah rasa gamang menghadapi gejala ini, sekurang-kurangnya dapat ditelaah perubahan corak dan isi propaganda kelompok-kelompok radikal, perubahan pola penyebaran dan kelompok target yang mau direkrut. Contohnya, dulu mereka menggunakan bentuk tekstual untuk menyebar gagasan radikal, sekarang mereka memakai pola visual yang menghasilkan efek kognitifnya yang jauh lebih kuat. Salah satu agenda yang mendesak adalah membangun gerakan fasih internet, dan bukan sekedar fasih-gawai. Fasih menggunakan gawai adalah perkara ketrampilan teknis. Namun, mengerti seluk beluk efek internet terhadap sikap, perilaku, cara merasa dan cara berpikir sama sekali bukan perkara teknis. Jangan-jangan, perbuatan yang kelihatan canggih (anak balita menggunakan ipad, remaja menghias facebook, orang berselancar di dunia maya, dan lain-lain) justru merupakan ciri digital illiteracy - buta aksara jenis baru. Semua itu tidak menutup kenyataan bahwa internet juga telah berubah men-

${ }^{13}$ Mark Juergensmeyer, Terror in the Mind of God: The Global Rise of Religions Violence (Berkeley: University of California Press, 2000). 
jadi medan yang subur bagi penyebaran gagasan demokratis, pengetahuan yang berguna, penghargaan pada kemajemukan dan komunikasi sehat lainnya. Itulah mengapa diperlukan pengguna maupun penulis-penulis di media sosial yang mampu menyebarkan pesan keagamaan moderat, sejuk, ramah, dan tidak menakutkan. Tentu saja diperlukan sikap untuk tetap berkepala dingin dan kemampuan kritis dalam membaca serta menanggapi gejala, dan terlebih-lebih sanggup menahan hasrat dan emosi. Banyak orang bergabung dengan gerakan militan bukan karena alasan rasional, melainkan pertimbangan emosional, dorongan hasrat, dan pengalaman moral/spiritualnya juga. Dengan pertimbangan ini, upaya merekonstruksi pola kognitif fundamentalis pun perlu dilengkapi dengan metode menelusuri hubungan pelik antara hasrat, emosi, nalar, pilihan moral dan spiritual. Sementara hasrat dan emosi membentuk motivasi, kepekaan moral dan gairah spiritual dapat meradikalkan atau memoderatkan motivasi.

Upaya-upaya rasional untuk mengendalikan kecenderungan menguatnya fundamentalisme dan radikalisme serta pelbagai dampaknya, tidak pernah memadai selama tidak mengaitkan rasional dengan hasrat dan emosi. Itulah mengapa, sekalipun deradikalisasi kerap dilakukan, tetap saja masih terjadi sebuah kecolongan. Hal ini dapat dilihat dari peristiwa beraksinya kembali tindakan terorisme yang dilakukan oleh Juhanda, pelaku teror di depan gereja Oikumene, Kelurahan Sengkotek, Samarinda, Kalimantan Timur. Juhanda telah menjalani deradikalisasi, namun masih memiliki niat menimbulkan kekacauan di Indonesia. Pelariannya ke Samarinda rupanya membuat Juhanda mengembangkan jaringan ${ }^{14}$. Nalar memiliki batas. Nalar membantu manusia mengenali macam-macam hasrat dan kehendak yang memicu seseorang untuk bertindak. Akan tetapi, memilih di antara peringkat kehendak berada di luar batas nalar. Sebagai contoh sederhana bagi hubungan antara emosi, hasrat dan moralitas, dapat dilihat dari perasaan malu yang muncul akibat suatu perbuatan keliru. Emosi berperan besar dalam membenarkan pilihan moral seseorang. Namun, malu tidak bangkit bila orang tidak dilatih untuk merasa malu karena melakukan yang salah, contohnya saja malu berbuat korupsi. Demikian halnya dengan spiritualitas. Bukan argumen akademik teologi dan filsafat yang mengisi jantung latihan spiritual.

Spiritualitas memiliki banyak wajah, yang dapat diartikan berbeda-beda menurut pandangan pribadi maupun agama. Spiritualitas tidak terlepas dari intelektualitas, tetapi emosi dan imajinasilah yang terutama menggerakkannya. Latihan spiritual dalam hampir semua agama pada umumnya diawali dengan praktik mengenali gerak emosi, baru kemudian diikuti dengan teknik mengendalikan dan merawat emosi. Di tingkat yang paling mentah emosi digerakkan oleh kebutuhan fungsional organisme untuk bertahan hidup dan berkembang biak. Disinilah kemampuan menggerakkan emosi mentah merupakan salah satu kekuatan teknik kelompok radikal untuk memancing minat para pemula.

Dari analisis ini, dapat dilihat bahwa aspek spiritual bukanlah yang pertama-tama menggerakkan motivasi orang untuk mengadopsi radikalisme agama. Kendati demikian, ke-

14 Viva.co.id, "Residivis-Terorisme-Kembali-Berulah-Deradikalisasi-Gagal," last modified 2016, http://www.viva.co.id/indepth/fokus/847689-residivis-terorisme-kembali-berulah-deradikalisasi-gagal. 
matangan spiritual, baik di tingkat pribadi maupun publik, akan mengembangkan imajinasi religius yang sehat. Emosi dan hasrat pun tidak cukup dimengerti hanya melalui pendekatan psikologis. Diperlukan adanya analisis antropologi filosofis dan teologi emosi untuk menyingkapkan ontologi rasa merasa yang menggerakkan orang menganut ideologi radikal. Teologi emosi yang dimaksud disini adalah bahwa dalam kitab suci banyak berbicara tentang emosi dan kaya dengan ungkapan-ungkapan emosi yang dapat dipelajari. Kitab Suci - dalam hal ini Alkitab - memberikan contoh tentang bagaimana emosi itu ditanggulangi dengan baik, misal ketika Yesus harus bergumul dengan keadaan (emosi) -Nya ketika bergumul di bukit Getsemani atau ketika Yesus ditinggalkan oleh murid-murid-Nya. Dengan mempelajari bagaimana cara menanggulangi emosi-emosi sebagaimana yang ada dalam Kitab Suci akan membuat para pelaku radikalisme mampu mengatur emosi dan tindakan mereka. ${ }^{15}$

Filsafat dan teologi tentu tidak dapat bekerja sendiri. Keduanya membutuhkan ilmuilmu lain untuk menopang refleksinya. Ringkasnya, perlu kerja sama lintas disiplin dan lintas budaya, selain penelitian sosiologis, ekonomi, dan politik yang banyak dijalankan. Perlu dipahami hubungan emosi dengan lingkungan sosial, kondisi moral, pendirian ideologis, pertimbangan nalar dan keadaan spiritualitas seseorang atau kelompok.

\section{Spiritualitas Orang Kristen}

Menurut KBBI, Spiritual berhubungan dengan atau bersifat kejiwaan (rohani, batin). ${ }^{16}$ Spiritualitas merupakan pengalaman subyektif yang memperhatikan mengapa hidup itu berharga, bukan sekedar apakah hidup itu berharga. ${ }^{17}$ Spiritualitas tidaklah sama dengan agama. Agama adalah ajaran, sistem yang mengatur tata keimanan (kepercayaan) dan peribadatan kepada Tuhan Yang Mahakuasa serta tata kaidah yang berhubungan dengan pergaulan manusia dan manusia serta lingkungannya. ${ }^{18}$ Agama merupakan praktek perilaku tertentu yang dihubungkan dengan kepercayaan yang dinyatakan oleh institusi tertentu yang dihubungkan dengan kepercayaan yang dianut oleh anggota-anggotanya. ${ }^{19}$ Agama bersifat komunal sedangkan spiritualitas tidak harus dinyatakan oleh institusi atau komunitas tertentu. Seseorang bisa saja mengikuti agama tertentu, namun memiliki spiritualitas. Orang-orang dapat menganut agama yang sama, tetapi belum tentu memiliki jalan atau tingkat spiritualitas yang sama.

Spiritualitas merupakan manusia seutuhnya dalam totalitas eksistensi di dunia, bukan beberapa fragmen atau bagian atau insiden dari seseorang. ${ }^{20}$ Spiritualitas menjawab tentang siapa dan apa seseorang itu dalam keberadaan dan kesadarannya secara individu, sekalipun orang tersebut tidak beragama. Hal ini ditegaskan oleh Andre Comte-Sponville dalam bukunya yang berjudul Spiritualitas Tanpa Tuhan. Buku tersebut mencoba membuktikan ungkap-

\footnotetext{
${ }^{15}$ Karlina Supelli, “Dua Jalan Percobaan Untuk Menanggapi Fundamentalisme Agama,” Jurnal Filsafat dan Teologi-Orientasi Baru - STF Driyarkara 25, no. 02 (2016): 218.

${ }^{16}$ KBBI, "Spiritual," last modified 2020, https://kbbi.web.id/spiritual.

${ }^{17}$ Gernaida Pakpahan, Pentacostal Spirituality: A Passion for The Kingdom (Jakarta, 2017).

18 KBBI, "Agama."

${ }^{19}$ Pakpahan, Pentacostal Spirituality: A Passion for The Kingdom.

${ }^{20}$ William Stringfellow, Politics of Spirituality (Philadelphia, PA: Westminster Press, 1984).
} 
an yang ia kutip dari Publishers Weekly bahwa "Tuhan menurut logika, tidak selalu dibutuhkan. Meskipun demikian, kita tetap bisa memiliki cinta, prilaku etis dan bahkan pengalaman abadi." 21 Dalam konteks kekristenan sendiri, spiritualitas berarti: yang dapat menghidupkan kehidupan iman seseorang atau menggerakkan iman seseorang ke dalam kesempurnaan yang lebih besar lagi. Spiritualitas kristen mempertimbangkan unsur-unsur seperti: seperangkat sistem nilai yang didasarkan atas pengharapan dan janji penebusan, kasih terhadap sesama, penyangkalan diri, dan juga cara hidup yang berisi kenyataan, kehidupan manusia dengan mana keyakinan-keyakinan dan nilai-nilai berakar dan diekspresikan dan cakupannya holistik karena tidak hanya menyangkut perilaku agama, tetapi juga sosial. ${ }^{22}$ Spiritualitas adalah suatu pengalaman yang dihidupi. Spiritualitas sejati berbicara tentang hubungan seseorang dengan Allah dibanding sekedar pengetahuan tentang-Nya. Pusat dari spiritualitas Kristen adalah Allah sendiri dengan kehadirannya di dalam diri setiap orang yang percaya. Pengenalan akan Alalh tidak bisa disamakan dengan sekedar menguasai teologi tertentu.

Spiritualitas sejati tidak berpusat pada kegiatan keagamaan yang superfisial, dan tidak didasari pada tatanan nilai moral serta kewajiban-kewajiban di dalamnya. Spiritualitas sjati adalah persekutuan dengan pribadi Kristus Yesus. Yesus memperingatkan murid-murid-Nya agar menghindari dan menjauhi praktek-praktek keagamaan yang sia-sia (Mat. 6). Lebih keras lagi teguran Yesus terhadap jemaat di Efesus dalam Wahyu 2:1-7, Yesus memuji kerajinan dan komitmn mereka dalam beribadah dan dalam melayani namun kehilangan kasih yang semula (spiritualitas yang kosong). Aktifitas rohani yang hebat dan luar biasa tidak menjamin kualitas spiritualitasnya bagus.

Dalam kekristenan sendiri, terdapat berbagai macam spiritualitas. Sebagai contohnya: spiritualitas golongan Injili dan golongan Pentakosta. Grenz mengungkapkan bahwa spiritualitas golongan Injili mencoba menyeimbangkan kesucian hati dan aktifitas pelayanan. Bagian dalam dari manusia (inward) merupakan fondasi dari spiritualitas. Spiritualitas Injili mencoba menyeimbangkan dimensi dalam dan dimensi luar dari hidup Kristen; menyeimbangkan hati yang hangat oleh kasih kepada Allah dengan hidup yang mengikuti teladan Yesus. ${ }^{23}$ Sedangkan dalam spiritualitas Pentakosta, ada beberapa penekanan yang diberikan; yang nampak dari karakteristik gereja Pentakosta itu sendiri, antara lain:

1. Lebih menekankan peranan Roh Kudus dalam kehidupan sehari-hari.

2. Tata laksana liturgi yang lebih sederhana, lagu rohani yang digunakan lebih modern.

3. Mengijinkan keterlibatan kaum perempuan dan kaum awam dalam pelayanan.

4. Panggilan pertobatan dan hidup dalam kesucian.

5. Menekankan panggilan untuk menjadi saksi hingga ke seluruh dunia sebagai bentuk tanggung jawab terhadap respon eskhatologis.

6. Memberi tempat untuk nubuat, bicara dalam bahasa roh sebagai bentuk nyata baptisan Roh Kudus.

\footnotetext{
${ }^{21}$ Andre Comte-Sponviile, Spiritualitas Tanpa Tuhan (Jakarta: Pustaka Alvabet, 2000).

${ }^{22}$ Junifrius Gultom, Teologi Misi Pentakostal - Isu-Isu Terpilih (Jakarta: Bethel Press, 2015).

${ }^{23}$ Stanley J. Grenz, Spiritualitas Injili: Suatu Tinjauan Ulang, 44/Triwula. (Lembaga Reformed Injili Indonesia, Momentum, 2000).
} 
7. Memberi kepedulian terhadap isu-isu sosial, keadilan, ekonomi, politik, ras, budaya, dll.

8. Komitmen yang kuat terhadap pelayanan praktis di gereja lokal. ${ }^{24}$

Sehingga, ketika berbicara mengenai spiritualitas Pentakosta, maka tidak bisa tidak, beberapa karakteristik di atas akan tercakup di dalamnya.

Spiritualitas Pentakosta adalah suatu pengalaman hidup dari konfigurasi khusus ajaran-ajaran, praktek-praktek dan sensibilitas yang meletakkan orang percaya pada suatu hubungan yang berkelanjutan dengan Roh Kudus. ${ }^{25}$ Spiritualitas Pentakosta mengejar kesucian di bawah pimpinan Roh Kudus, dalam hidup yang memuliakan Allah, dalam persatuan dengan Kristus dan ketaatan kepada Roh Kudus. Sekalipun orang Pentakosta sangat memperhatikan ortodoksi (keyakinan yang benar), mereka juga menekankan ortopati (perasaan yang benar) dan ortopraksis (refleksi atau tindakan yang benar). Tindakan yang benar harus diperlihatkan dalam kehidupan sehari-hari. Spiritualitas orang Kristen (baik itu spiritualitas golongan Injili maupun Pentakosta) haruslah sama dengan spiritualitas Kristus, yaitu bergerak di dalam religiositas Kerajaan Allah. Suatu religiositas yang memandang bahwa Sabat untuk manusia dan bukan manusia untuk Sabat. Religiositas yang lebih memandang esensi dalam ibadah, yaitu keadilan dan kasih (Luk. 11), bukan kepada spiritualitas penyembahan yang tidak berkorelasi dengan kenyataan hidup sehari-hari. Spiritualitas Kristus sangat bertolak belakang dengan spiritualitas ahli-ahli Taurat dan orang-orang Farisi, yang begitu dogmatis menghidupi hukumhukum Allah. ${ }^{26}$ Dalam tulisan-tulisan Paulus, Kerajaan Allah dilihat dari dua aspek: menekankan aspek doktrinal dan aspek tataran aplikatif. Hasil dari bergabungnya seseorang dalam Kerajaan Allah tidak hanya dapat dilihat pada aspek teologis (apa yang telah Allah kerjakan), tetapi juga aspek etis (apa yang harus manusia lakukan). Aspek etis Paulus terdiri dari karunia dalam pelayanan, konsekrasi dalam dinamika hidup, kasih pada keluarga, kepedulian pada sesama dan kepekaan terhadap ciptaan.

\section{Kesimpulan}

Spiritualitas orang Kristen yang dihadirkan dalam bermasyarakat seharusnya memberikan keteduhan bagi masyarakat plural di Indonesia, bukan justru menimbulkan kegaduhan. Sikap radikal orang Kristen dalam menjalankan imannya tidak harus diwujudkan melalui demonstrasi ekstrim sebagaimana yang dicontohkan dalam permasalahan di atas sebelumnya tetapi tindakan radikal orang kristen haruslah mampu membawa orang Kristen menjadi saksi dan membawa damai, keadilan dan kasih bagi sesamanya; menunjukkan kepedulian terhadap sesama dan masyarakat.

Spiritualitas orang kristen pun harus menjamah bidang pendidikan, di mana pendidikan merupakan dasar pembentukan kognitif seseorang. Pembinaan pendidikan harus dilakukan baik di gereja maupun dalam keluarga dan bermasyarakat. Inilah yang akan mengantisipasi

\footnotetext{
${ }^{24}$ Pakpahan, Pentacostal Spirituality: A Passion for The Kingdom.

${ }^{25}$ Gultom, Teologi Misi Pentakostal - Isu-Isu Terpilih.

${ }^{26}$ Ibid.
} 
masuknya tindakan radikalisme. Melihat banyaknya kalangan pemuda yang mendukung (dari survey yang peneliti tuliskan sebelumnya) tindakan radikalisme, maka peneliti setuju kepada pernyataan Supelli, bahwa selain pendidikan, pembinaan emosi pun harus mendapatkan perhatian khusus agar pemuda tidak mudah terseret arus radikalisme yang digembor-gemborkan melalui media, baik media sosial maupun chatroom.

Upaya pengkritisan juga harus dilakukan terhadap tafsir keagamaan yang bersifat ekstrem dengan melihat kembali makna-makna substantif agama. Dalam gereja sendiri, pendidikan teologi menjadi sangat penting sehubungan dengan latar belakang dari pelaksana radikal Kristen adalah orang-orang yang biasanya tidak mengenyam pendidikan teologi. Kebanyakan dari mereka seorang yang terjun dalam pelayanan dan mengajarkan apa yang mereka pelajari berdasarkan pengalaman dan pemahaman pribadi dari para pemimpin yang mereka anggap benar. Pendidikan teologi bermanfaat untuk meluruskan cara penafsiran bahkan cara mengaplikasikan sebuah ayat dalam Alkitab ke dalam konteks dimana orang kristen tinggal saat ini. Pendidikan teologi juga bermanfaat bagi para pelaku teologi praktis untuk bersifat arif dan bijaksana ketika mereka melakukan kegiatan mereka di lapangan. Terkadang para pelaku kegiatan yang cenderung menjadi radikal sudah memiliki penolakan terhadap dunia teologi. Dunia teologi dianggapnya sangat normatif dan kurang menyentuh kebutuhan umat Tuhan. Anggapan yang seperti itu harus dirubah secara total mengingat bahaya yang riil yang mengancam eksistensi kesatuan dan keharmonisan umat beragama pada umumnya.

Upaya untuk mendorong secara lebih lebar atau luas lagi diskusi publik tafsir agama pun dapat meminimalisasi adanya kontradiksi penafsiran atas suatu ayat atau teks agama. Cara ini pula dapat menyingkap kepentingan terselubung di balik tafsir yang lebih mengobarkan semangat permusuhan daripada jalinan persaudaraan. Para pemimpin umat beragama harus menyediakan waktu untuk berdiskusi bersama guna menyelaraskan pemahaman mereka sehingga kerukunan antar umat beragama bisa terjadi. Dari hasil diskusi tersebut pemimpin gereja dapat meneruskan hasilnya untuk mengedukasi jemaat sehingga jemaat memiliki pemahaman yang baik terutama dalam mengaplikasikan pemahamannya dalam kerangka hubungan dengan umat beragama yang lain. Umat beragama yang saling mengenal dan membuka diri terhadap umat lain akan berdampak bagi keharmonisan hidup mereka. Kecenderungan keradikalan yang berdampak biasanya karena umat beragama menutup diri dan merasa tidak memerlukan komunikasi atau pengenalan dengan umat beragama yang lain.

Pendidikan mengenai nilai kebangsaan tidak boleh terluput dari upaya-upaya gereja untuk melawan radikalisme. Sosialisasi bagaimana menghormati lambang negara, ideologi bangsa, pemimpin negara, dan nilai-nilai yang dianut dalam bernegara dan ber-bhineka haruslah mendapat tempat di dalam gereja. Hal ini dapat dilakukan melalui kotbah-kotbah di gereja, tulisan-tulisan rohani yang bernuansa kebangsaan, ataupun seminar-seminar kebangsaan. Sosialisasi tersebut diharapkan akan meminimalkan dampak yang bersentuhan langsung dengan disharmonisasi dan toleransi umat beragama di Indonesia. Dengan adanya upaya-upaya yang dilakukan seperti yang peneliti jabarkan di atas, maka tidaklah mustahil bila spiri- 
tualitas orang Kristen pada akhirnya menghadirkan Kerajaan Allah di tengah tantangan radikalisme di bangsa ini.

\section{Rujukan}

Agustin Soewitomo, Putri. “Tips Dan Trik Pemilihan Dan Penyusunan Literatur Review.” In Strategi Menulis Jurnal Untuk Ilmu Teologi, 44. Golden Gate Publishing, 2020.

Bbc.com. "The Pew Research Center."

cnnindonesia. "Gerindra-Tunggu-Putusan-Mk-Untuk-Koreksi-Uu-Ormas."

Comte-Sponviile, Andre. Spiritualitas Tanpa Tuhan. Jakarta: Pustaka Alvabet, 2000.

F. Budi Hardiman (ed.), Franz Magnis Suseno. Tribalisme Menabrak Demokrasi Dalam Sosok Dan Pemikirannya Frans Magnis Suseno. Jakarta: Penerbit Kompas, 2016.

Grenz, Stanley J. Spiritualitas Injili: Suatu Tinjauan Ulang,. 44/Triwula. Lembaga Reformed Injili Indonesia, Momentum, 2000.

Gultom, Junifrius. Teologi Misi Pentakostal - Isu-Isu Terpilih. Jakarta: Bethel Press, 2015.

Juergensmeyer, Mark. Terror in the Mind of God: The Global Rise of Religions Violence. Berkeley: University of California Press, 2000.

KBBI. "Agama."

"Makar."

"Radikal."

"Radikalisme.” Last modified 2020. https://kbbi.web.id/radikalisme.

_. "Spiritual.” Last modified 2020. https://kbbi.web.id/spiritual.

Kompas. “Jajak Pendapat Kompas: 'Konflik Identitas Dan Kegaduhan Politik,” 2016.

Novalina, Martina. Di Bawah Kepak Sayap Sang Garuda (Pemahaman, Sikap Dan Tindakan Fundamental Keber-Agama-an Dalam Bingkai Pancasila). Edited by Tim STT Ekumene. 1st ed. Jakarta: Rehobot Literature, 2018.

Pakpahan, Gernaida. Pentacostal Spirituality: A Passion for The Kingdom. Jakarta, 2017.

pewglobal. "Http://Www.Pewglobal.Org/2017/08/01/Globally-People-Point-to-Isis-andClimate-Change-as-Leading-Security-Threats/."

Sastrapratedja, M. Pancasila: Lima Gagasan Yang Dapat Mengubah Indonesia. Jakarta: Pusat Kajian Filsafat dan Pancasila, 2013.

Stringfellow, William. Politics of Spirituality. Philadelphia, PA: Westminster Press, 1984.

Supelli, Karlina. "Dua Jalan Percobaan Untuk Menanggapi Fundamentalisme Agama.” Jurnal Filsafat dan Teologi-Orientasi Baru - STF Driyarkara 25, no. 02 (2016): 218.

Viva.co.id. "Residivis-Terorisme-Kembali-Berulah-Deradikalisasi-Gagal." Last modified 2016. http://www.viva.co.id/indepth/fokus/847689-residivis-terorisme-kembaliberulah-deradikalisasi-gagal. 